\title{
Penajaman Citra Satelit Landsat 8 Menggunakan Transformasi Brovey
}

\author{
I Made Dhanan Pradipta ${ }^{1}$, I Made Oka Widyantara ${ }^{2}$, Rukmi Sari Hartati ${ }^{3}$ \\ Submission: 19-08-2019, Accepted: 20-10-2019
}

\begin{abstract}
Image sharpening is an image optimization technique by combining two satellite images by taking advantage of each images, so that the output image has good spectral and spatial quality. Image sharpening is an alternative to facilitate the recognition of an object, moreover for Landsat satellites has many bands that can be used as samples for the image sharpening process. One method used in image sharpening is Brovey Transformation. This method is widely used because it is very simple and easy in making the algorithm. The Bands which is used in the image sharpening process are composite bands (red, green, and blue) with panchromatic bands from the Landsat 8 satellite. The results of the image sharpening process are high spectral images obtained from composite images and spatial values obtained from panchromatic images. Analysis of the results of image sharpening using the Brovey Transform method is done by comparing the quality of the truecolor image before sharpened and the image that has been sharpened by calculating the maximum and minimum values of the red, green and blue bands, analyzing the mean values and also the standard deviation values of each image
\end{abstract}

Key Words - Brovey Transformation, Composite, Image Sharpening, Landsat 8

Intisari- Penajaman citra adalah teknik optimasi citra dengan cara mengkombinasi dua citra satelit dengan mengambil kelebihan yang dari tiap citra sehingga citra output memiliki kualitas spektral dan spasial yang baik. Penajaman citra dilakukan sebagai alternative untuk memudahkan pengenalan suatu objek, terlebih lagi untuk satelit Landsat mempunyai banyak band yang mampu dijadikan sampel untuk proses penajaman citra. Metode yang digunakan dalam penajaman citra salah satunya adalah Transformasi Brovey. Metode ini banyak digunakan karena sangat simple dan mudah dalam pembuatan algoritmanya. Band yang digunakan dalam proses penajaman citra yaitu composite band (red, green, dan blue) dengan pankromatik band dari satelit landsat 8. Hasil dari proses penajaman citra adalah citra dengan spectral yang tinggi didapat dari citra composite serta nilai spasial yang didapat dari

\footnotetext{
${ }^{1}$ Mahasiswa Pascasarjana, Program Studi Magister Teknik Elektro Fakultas Teknik Universitas Udayana, Jln. Kampus Bukit Jimbarang 80361 INDONESIA (telp: 0361-555225; fax: 03614321982; danan.dipta@gmail.com)

${ }^{2,3}$ Dosen,Jurusan Teknik Elektro dan Komputer Fakultas Teknik Universitas Udayana, Jln. Jalan Kampus Bukit Jimbaran 80361 INDONESIA (telp: 0361-703315; fax: 0361-4321; e-mail: oka.widyantara@unud..ac.id rukmisari@unud.ac.id)

citra pankromatik. Analisa hasil dari penajaman citra dengan metode Transformasi Brovey dilakukan dengan membandingkan kualitas dari citra truecolor sebelum ditajamkan dan citra yang sudah ditajamkan dengan cara menghitung nilai maksimun dan minimun dari band red, green
}

dan blue, analisa nilai mean dan juga nilai standar deviasi dari masing-masing citra

Kata Kunci- Composite, Landsat 8, Penajaman Citra, Transformasi Brovey

\section{PENDAHULUAN}

Sistem sensor pada satelit remote sensing, yaitu nilai spasial dan nilai spectral pada citra merupakan hal yang berlawanan. Satelit remote sesning dapat menghasilkan citra dengan nilai multispektral yang dapat membedakan objek secara spektral namun tidak secara spasial, begitu pula sebaliknya [1].

Sensor pada satelit remote sensing dapat menghasilkan kenampakan data pankromatik yang memiliki resolusi spasial tinggi, sedangkan citra multispektral yang memiliki resolusi spasial lebih rendah seperempat kali. Citra pankromatik memiliki rentang atau range gelombang lebih dari kanal multispektral. Prinsip dari sensor pankromatik adalah sekali melakukan perekanan data yang dihasilkan lebih kecil dibandingkan sensor multispektral, dimana kedua sensor sama-sama berfungsi sebagai penerima energi, tetapi sensor dari pankromatik menghasilkan lebih banyak nilai spasial pada satu kalo perekaman. Jika digabungkan antara citra pankromatik dengan nilai spasial tinggi dan citra multispektral dengan nilai spasial rendah akan lebih kecil daripada citra multispektral yang memiliki nilai spasial yang tinggi [2]. Perbedaan itu sangat mempengaruhi penggunaan data citra satelit dalam berbagai proses pengolahan citra (image processing)

Data remote sensing pada umumnya memerlukan pengenalan objek pada lapisan bumi dengan akurat dan bisa membedakan satu objek dengan lainnya. Teknik pengolahan citra digital khususnya identifikasi objek sangat memerlukan kejernihan citra dalam membedakan tekstur, bentuk, warna ataupun Batasan pada suatu daerah objek yang memiliki nilai resolusi kecil atau minim. Berdasarkan permasalahan tersebut teknik penajaman citra sangat penting dilakukan [3].

\section{KAJIAN PUSTAKA}

\section{A. Remote Sensing}

Remote sensing atau penginderaan jauh adalah teknik yang dikembangkan untuk perolehan dan analisis informasi tentang bumi, informasi tersebut berbentuk radiasi elektromagnetik yang dipantulkan atau dipancarkan dari permukaan bumi. Penginderaan jauh terdiri atas pengukuran dan perekaman terhadap energi elektromagnetik yang dipantulkan atau dipancarkan oleh permukaan bumi dan atmosfer dari suatu tempat tertentu di permukaan bumi [4]. 
Citra yang biasa digunakan di dalam remote sensing yaitu citra data pankromatik, dengan kanal abu-abu yang prinsipnya mempunyai nilai spasial yang tinggi, sehingga dapat difungsikan untuk mengidentifikasi suatu daerah yang berisikan objek-ibjek tertentu. Citra multispektral dengan kanal multispektrum menghasilkan nilai warna berdasarkan refleksi dan absorbsi elektromagnetik yang dikeluarkan oleh objek-objek tertentu pada proses perekaman. Prinsipnya citra multispektral memiliki resolusi spasial rendah namun mampu memberikan spectral yang tinggi [5].

\section{B. Penajaman Citra (Pansharpening)}

Penggabungan citra pankromatik dan citra multispektral dikenal dengan istilah penajaman citra atau pansharpening. Penajaman citra umumnya adalah suatu metode untuk mengkombinasikan nilai spasial resolusi tinggi dari citra pankromatik dengan citra multispektral dengan resolusi rendah, dimana umumnya dua atau lebih gambar integrasikan menjadi satu citra dengan mempertahankan fitur penting dari masing-masing gambar kombinasi. Tujuan penajaman citra yaitu mengintegrasikan data yang didapat dari sumbersumber tertentu untuk mendapatkan informasi yang jauh lebih baik dibandingkan dengan menggunakan satu informasi saja [5].

\section{Citra Multispektral}

Citra multispektral yaitu citra yang terdiri dari saluran lebih dari satu (multi). Berbanding terbalik dengan citra yang mempunyai satu saluran yang terdiri dari saluran lebar. Citra multispektral prinsipnya terdiri dari saluran sempit. Sensor multispektral digunakan untuk merekam citra dengan banyak saluran, yang bertujuan untuk mengidentifikasi kenampakan dari objek tertentu, ini dikarenakan saluran tersebut mempunyai kepekaan terhadap objek [6]. Panjang gelombang pada citra remote sensing dibatasi oleh jendela inframerah dan jendela optik. Range gelombong biasanya bermacam, dan itu dipengaruhi oleh instrumen dari sensor, contoh Panjang gelombang dan fungsi nya antara lain:

1) Kanal Biru, Panjang gelombang 450-515 nm, berfungsi untuk pencitraan atmosfer dan air yang dalam, dan dapat mencapai hingga 150 kaki $(50 \mathrm{~m})$ jauh di air yang jernih.

2) Kanal Hijau, Panjang gelombang 515-600 nm, berfungsi untuk pencitraan vegetasi dan struktur air yang dalam, hingga 90 kaki $(30 \mathrm{~m})$ di air jernih.

3) Kanal Merah, Panjang gelombang 600-690 nm, berfungsi untuk pencitraan benda buatan manusia, dalam air hingga 30 kaki (9 m) dalam, tanah, dan vegetasi.

4) Kanal Dekat inframerah, Panjang gelombang 750-900 nm, berfungsi untuk pencitraan vegetasi.

5) Kanal Mid-inframerah, Panjang gelombang 1550-1750 $\mathrm{nm}$, berfungsi untuk pencitraan, kadar air tanah, dan beberapa kebakaran hutan.

6) Kanal Mid-inframerah, 2080-2350 nm, berfungsi untuk pencitraan tanah, kelembaban, fitur geologi, silikat, tanah liat, dan kebakaran.

7) Kanal Inframerah termal, Panjang gelombang 10.400$12.500 \mathrm{~nm}$, sensor menggunakan radiasi yang dipancarkan bukan tercermin, berfungsi untuk perekaman pencitraan struktur geologi, perbedaan termal dalam arus air, kebakaran, dan untuk studi malam [7].

ISSN $1693-2951$
Satelit landsat 8 band yang digunakan dalam proses composite dengan output citra multispektral yaitu band 2 (blue), band 3 (green), band 4 (red), seperti ditunjukan oleh gambar 1 .

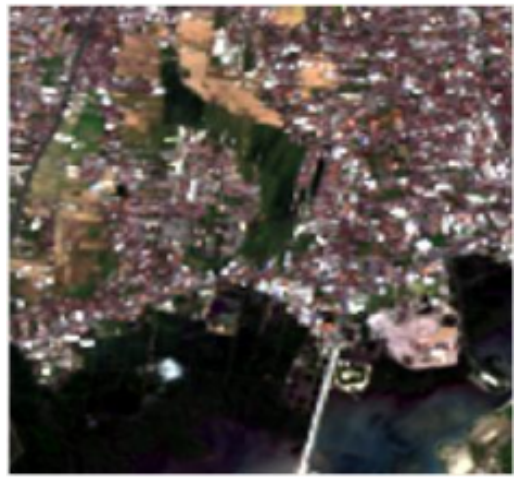

Gambar 1: Citra Multispektral

\section{Citra Pankromatik}

Citra pankromatik adalah sebuah citra yang dibuat dengan menggunakan banyak spektrum, yang umunya memiliki kenampakan bisa dilihat oleh mata manusia dari warna merah sampai warna ungu. Ciri-ciri dari citra pankromatik adalah citra dengan objek yang memiliki warna sama dengan apa yang dilihat mata manusia biasa, sehingga sangat cocok dalam pendeteksiani pencemaran air, penyerapan air tanah, kerusakan banjir, dan air permukaan. Pada Satelit Landsat citra pankromatik terletak pada Band 8 dimana memiliki spasial 15 meter dari permukaan bumi.

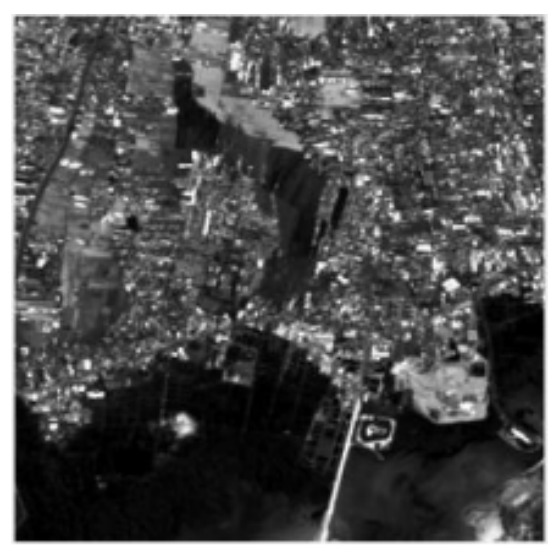

Gambar 2: Citra Pankromatik

\section{E. Satelit Landsat 8}

Satelit Landsat 8 memiliki dua sensor yaitu Operational Land Imager (OLI) dan Thermal Infrared Sensor (TIRS) dimana berfungsi untuk menyediakan cakupan dari daratan dengan resolusi spasial 30 meter (Visible, NIR, SWIR), 100 meter (Thermal) dan 15 meter (Pankromatik) [8]. Sensor citra OLI (Operational Land Imager) pada Landsat 8 memiliki satu kanal nearinfrared dan tujuh kanal tampak yang memilik range spektrum elektromagnetik yang dipantulkan oleh daerah yang berisikan objek-objek tertentu pada lapisan bumi, 
dimana semua kanal memiliki resolusi spasial 30 meter. Satelit Landsat 8 digunakan untuk berorientasi pada kebutuhan data informasi lainnya, banyak faktor yang menjadi penentu di dalam melaksanan kasus identifikasi atau pemetaan, pengelolaan sumber daya, perencanaan suatu wilayah dan lingkungan serta pengelolaan kesiapan bencana alam dan lainnya

Penggabungan citra yang dihasilkan oleh Satelit Landsat 8 , yang berada pada daerah dan waktu yang sama. sehingga dapat dilakukan penilitian untuk menganalisis perubahan secara kontinu pada objek-objek dilapisan bumi.

Sekali melakukan sensor, satelit Landsat 8 menghasilkan 11 band yaitu sebagai berikut [9].

TABEL I

BAND PADA SATELIT LANDSAT 8

\begin{tabular}{|l|l|l|}
\hline \multicolumn{1}{|l|}{ Jenis Band } & Range $(\mu \mathrm{m})$ & Nomer Band \\
\hline $\begin{array}{l}30 \mathrm{~m} \\
\text { Coastal/Aerosol }\end{array}$ & $0.435-0451$ & Band 1 \\
\hline $30 \mathrm{~m}$ Blue & $0.452-512$ & Band 2 \\
\hline $30 \mathrm{~m}$ Green & $0.553-0.590$ & Band 3 \\
\hline $30 \mathrm{~m}$ Red & $0.636-0.673$ & Band 4 \\
\hline $30 \mathrm{~m}$ NIR & $0.851-0.879$ & Band 5 \\
\hline $30 \mathrm{~m}$ SWIR -1 & $1.566-1.651$ & Band 6 \\
\hline $100 \mathrm{~m}$ TIR -1 & $10.60-11.19$ & Band 10 \\
\hline $100 \mathrm{~m}$ TIR -2 & $11.50-12.51$ & Band 11 \\
\hline $30 \mathrm{~m}$ SWIR -2 & $2.107-2.294$ & Band 7 \\
\hline $15 \mathrm{~m}$ Pan & $0.503-0.676$ & Band 8 \\
\hline $10 \mathrm{~m}$ Cirrus & $1.363-1.384$ & Band 9 \\
\hline
\end{tabular}

\section{F. Transformasi Brovey}

Salah satu metode dalam penajaman citra yaitu Trasnfomasi Brovey. Transformasi Brovey adalah yang terbilang mudah untuk menggabungkan data dari sensorsensor yang berbeda, tetapi memiliki kelemahan yang hanya dapat mengkombinasikan tiga kanal spectral, yaitu merah, hijau dan biru. Transformasi Brovey berfungsi untuk menormalisasikan tiga saluran spectral sebagai bahan kombinasi citra RGB. Output dari nilai yang sudah dinormalisasikan akan dikali [9].

dengan saluran data citra pankromatik. Formula yang digunakan dijelaskan pada 1

$$
\begin{aligned}
& \text { Red }=\frac{\text { Band } 4}{\text { Band } 2+\text { Dand } \mathrm{a}+\text { Dand } 4} \times \mathrm{Pan} \\
& \text { Green }=\frac{\text { Band } \mathrm{g}}{\text { Dandz+Dand } \mathrm{x}+\text { Band } 4} \times \mathrm{Pan} \\
& \text { Blue }=\frac{\text { Band } \mathrm{z}}{\text { Band } 2+\text { Band } \mathrm{s}+\text { Dand } 4} \times \text { Pan }
\end{aligned}
$$

Keterangan :

Red = Hasil nilai Band Red

Green = Hasil nilai Band Green

Blue = Hasil nilai Band Blue

I Made Dhanan Pradipta : Penajaman Citra Satelit Landsat ...
Band $2=$ Nilai DN Band 2

Band 3 = Nilai DN Band 3

Band $4=$ Nilai DN Band 4

Pan = Nilai DN Band Pan $($ Band 8$)$

\section{G. Metode Penelitian}

Kerangka berpikir adalah gambaran secara umum dari system yang akan dibuat, dan bagaimana prosesnya berjalan. Proses inti ditunjukan pada gambar 1

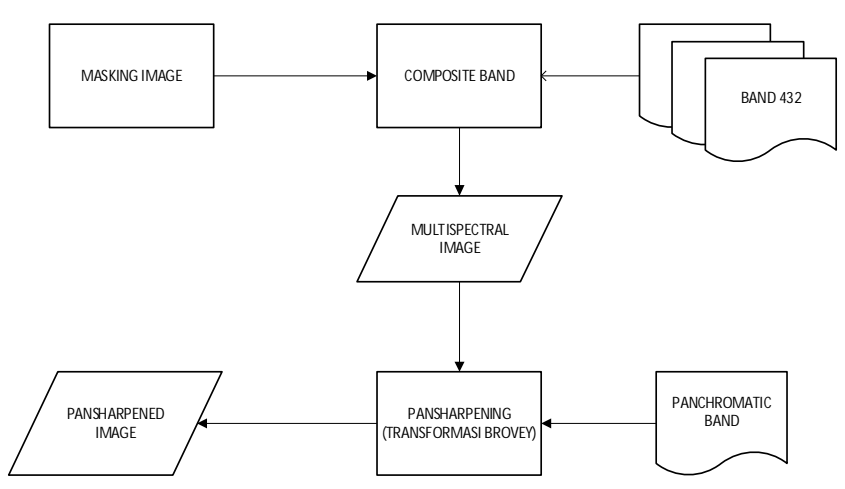

Gambar 3: Gambaran Umum Sistem

\section{H. Masking Citra}

Citra satelit yang pertama dimasking adalah multispektral. Dua titik yang dipotong akan disimpan yang selanjutnya akan digunakan untuk memotong citra yang kedua yaitu citra RGB sehingga kedua citra akan memiliki ukuran yang sama setalah dilakukan proses masking

\section{Composite Band}

Composite Band adalah proses penggabungan 3 buah band yaitu band 4 (red), band 3 (green) dan band 2 (blue) untuk mendapatkan citra multispektral sebagai salah satu citra yang akan ditajamkan. Nilai digital number dari 3 buah band akan digabungkan menjadi satu citra, dan membentuk citra RGB ata biasa disebut Truecolor.

\section{J. Pansharpening}

Proses penajaman citra atau pansharpening dengan memproses nilai pixel (Digital Number) dari band-band yang digunakan. Digital Number merupakan suatu penamaan untuk kotak yang manjadi bagian terkecil pada ssebuah citra digital. Angka numerik satu byte dari tiap piksel disebut Digital Number (DN). Digital Number biasanya diwakilkan dalam sebuah warna, yaitu kelabu, dengan rentang warna antara putih dan hitam, tergantung tingkatan gelombang yang dideteksi [7]. Digital Number suatu citra diperbesar maka akan terlihat beberapa kotak yang merupakan resolusi spasial dari citra tersebut. Sebelum menggunakan algoritma Brovey untuk proses penajaman citra yang pertama dilakukan adalah proses sampling

\section{1) Sampling}

Sampling berfungsi untuk meningkatkan nilai dari citra multispektral mendekati nilai pixel dari citra pankromatik p-ISSN:1693 - 2951; e-ISSN: 2503-2372 
sehingga kedua citra dapat digabungkan. Teknik sampling yang digunakan yaitu teknik nearest neighbor (Interpolasi tetangga) nearest neighbor adalah pendekatan yang paling sederhana untuk proses interpolasi. Metode ini menentukan pixel "terdekat" dengan pixel tetangga yang dalam hal ini adalah pixel citra pankromatik, dan mengasumsikan nilai intensitas dari citra multispektral

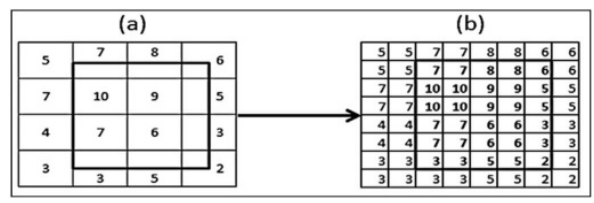

Gambar 4: Proses Sampling

Pixel citra (a) yang disampling $1 / 2$ dari resolusi spasial asli (misalnya, dari $30 \mathrm{~m}$ menjadi resolusi $15 \mathrm{~m}$ ) dengan menggunakan teknik nearest neighbor, dan nilai-nilai intensitas pixel citra yang sudah disampling ditunjukkan pada gambar (b).

2) Transformasi Brovey

Proses dari transformasi brovey menggunakan digital number yang sudah tersampling. Contoh perhitungan manual dari penajaman citra menggunakan metode brovey dijelaskan pada gambar 4. Sample citra multispektral dengan pixel $4 \times 4$ dengan nilai tiap pixel (digital number) yang sudah ditentukan.

\begin{tabular}{|l|l|l|l|}
\hline Band 4=9793 & $\ldots .$. & & \\
Band 3=8703 & & & \\
Band 2=7099 & & & \\
\hline & & & \\
& & & \\
\hline & & & \\
& & & \\
\hline & & & \\
\hline
\end{tabular}

Gambar 5: Sample citra RGB

Citra pankromatik yang digunakan sebagai penggabungan berukuran sama yaitu $4 \times 4$ tapi memiliki spasial yang lebih rapat (tinggi) ditunjukan oleh gambar 5.

\begin{tabular}{|l|l|l|l|}
\hline Band 8=6824 & $\ldots$. & & \\
\cline { 1 - 4 } Band 8=6824 & & & \\
\hline & & & \\
\hline & & & \\
\hline & & & \\
\hline & & & \\
\hline
\end{tabular}

Gambar 6: Sample Citra Pankromatik

ISSN $1693-2951$
Perhitungan manual untuk transformasi brovey dengan kedua sample citra multispektral dan citra pankromatik

$$
\begin{aligned}
& \text { Red }=\frac{9798}{7099+8708+9799} \times 6824=2610 \\
& \text { Green }=\frac{9703}{7099+9703+9793} \times 6824=2320 \\
& \text { BLue }=\frac{7099}{7099+9702+9792} \times 6824=1892
\end{aligned}
$$

\begin{tabular}{|l|l|l|l|}
\hline Band 4=2610 & $\ldots \ldots$ & & \\
Band 3 = 2320 & & & \\
Band 2 = 1892 & & & \\
\cline { 1 - 1 } Band 4=2610 & & & \\
Band 3 = 2320 & & & \\
Band 2 = 1892 & & & \\
\hline & & & \\
\hline & & & \\
\hline & & & \\
\hline & & & \\
\hline
\end{tabular}

Gambar 7: Hasil Dari Penajaman Citra

Hasil yang didapat ditunjutkan oleh gambar 6, dimana kerapatan atau spasial mengikuti citra pankromatik sehingga citra yang dihasilkan lebih jelas dan mempunyai nilai red, green dan blue sesuai dengan penajaman citra dengan metode algoritma transformasi brovey.

\section{HASIL DAN PEMBAHASAN}

\section{A. Pengukuran Kualitas Citra}

Analisis citra diperlukan untuk mengetahui informasi penting dari sebuah citra. Informasi tersebut dapat berupa: statistik citra, analisis wilayah (region analysis), dan analisis tekstur.

Analisis statistik merupakan salah satu jenis analisis citra yang digunakan untuk mengetahui data statistik citra, diantaranya berupa:

1) Mean (nilai rata-rata) citra

2) Standar deviasi (simpangan baku) citra

3) Nilai Min dan Max pada citra

Hasil dari analisis statistik citra dapat digunakan untuk menentukan langkah berikutnya dalam pengolahan citra

1) Nilai Min dan Max

Nilai min dan max pada citra didapatkan menggunakan histogram analisis, dimana nilai min dan max dihitung di tiap band yaitu red, green dan blue

2) Mean

Mean adalah nilai rata-rata dari seluruh piksel citra (elemen matriks) [10]. 
Majalah Ilmiah Teknologi Elektro, Vol. 18, No. 3, September-Desember 2019

DOI: https://doi.org/10.24843/MITE.2019.v18i03.P08

$\mu=\frac{1}{M N} \sum_{i=1}^{M} \sum_{j=1}^{N} A_{(i n)}$

Keterangan :

$\mathrm{S}=$ Standar deviasi

$\mathrm{X}=$ rata-rata sampel

Keterangan :

$A_{(i, j)}=$ nilai piksel citra $\mathrm{A}$ pada baris $\mathrm{i}$ dan kolom $\mathrm{j}$

$\mathrm{M}=$ ukuran baris citra

$\mathrm{N} \quad=$ ukuran kolom citra

$\mathrm{N}=$ jumlah matriks

Berikut adalah contoh dua buah sampel yang digunakan untuk melihat kualitas dari citra setelah ditajamkan dibandingkan dengan citra multispektral awal.

\section{3) Standard Deviasi}

Standar deviasi ialah sebuah nilai statistik yang di manfaatkan dalam penentuan sebaran menentukan sebuah rangkaian data pada suatu sampel citra, dan juga hubungan antara titik-titik data rata - rata nilai sampel nya [10].

$S=\frac{\sum(X i-X)^{2}}{n-1}$



(a)

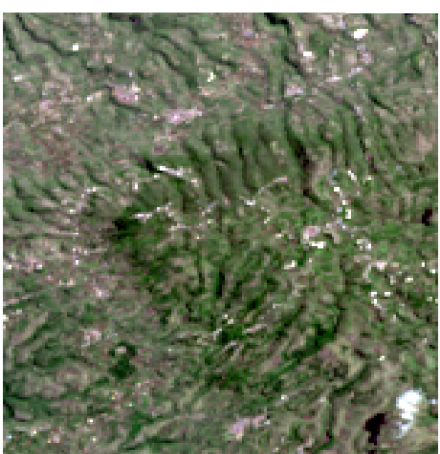

(d)

(3)



(b)

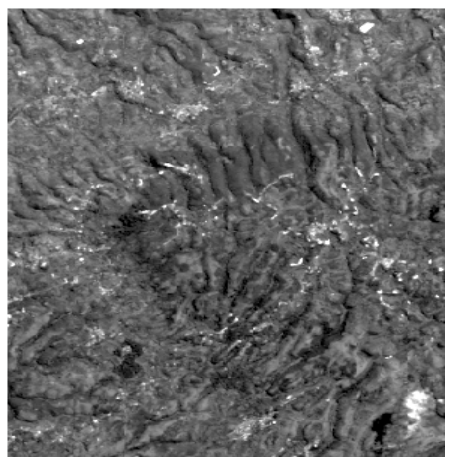

(e)

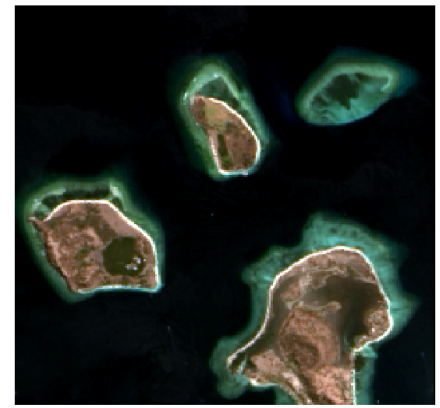

(c)

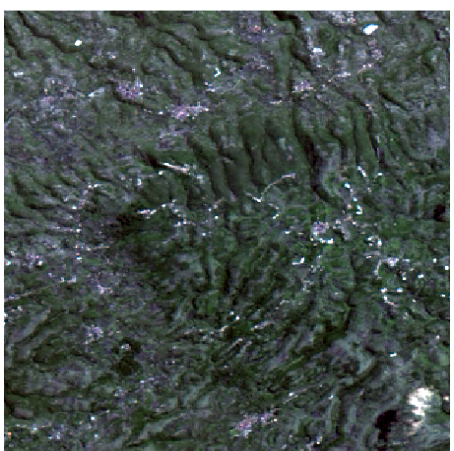

(f)

Gambar 8: Sample Citra

(a) sample citra multispektral A, (b) sample citra pankromatik A, (c) output Transfomasi Brovey citra A

(d) sample citra multispektral B, (e) sample citra pankromatik B, (f) output Transfomasi Brovey citra B

TABEL II



\begin{tabular}{|c|c|c|c|c|c|c|}
\hline \multirow{2}{*}{ Nama } & \multicolumn{2}{|l|}{ Citra Truecolor A } & \multicolumn{2}{l|}{ Citra Pansharpen A } \\
\cline { 2 - 7 } & Band 4 & Band 3 & Band 2 & Band 4 & Band 3 & Band 2 \\
\hline Min & 6175 & 7033 & 8531 & 1874 & 2155 & 2435 \\
\hline Max & 14395 & 13178 & 12786 & 5545 & 5231 & 5244 \\
\hline
\end{tabular}

I Made Dhanan Pradipta : Penajaman Citra Satelit Landsat ... 


\begin{tabular}{|l|c|c|c|c|c|c|}
\hline Mean & 6919.4517 & 7801.7515 & 9064.0483 & 2175.3596 & 2450.5431 & 2840.3753 \\
\hline Std & 1151.4029 & 994.1676 & 535.7812 & 430.5099 & 384.9650 & 251.2474 \\
\hline
\end{tabular}

TABEL III

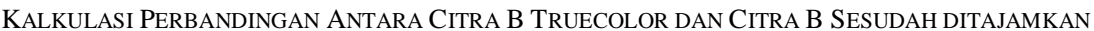

\begin{tabular}{|l|c|c|c|c|c|c|}
\hline \multirow{2}{*}{ Nama } & \multicolumn{2}{|l|}{ Citra Truecolor B } & \multicolumn{2}{l|}{ Citra Pansharpen B } \\
\cline { 2 - 7 } & Band 4 & Band 3 & Band 2 & Band 4 & Band 3 & Band 2 \\
\hline Min & 6221 & 6973 & 8134 & 0.0000 & 0.0000 & 0.0000 \\
\hline Max & 19904 & 17134 & 15153 & 7277 & 6817 & 6230 \\
\hline Mean & 7516.3820 & 8363.1604 & 8810.7262 & 2417.4783 & 2689.7394 & 2833.5299 \\
\hline Std & 598.2814 & 421.9361 & 333.3595 & 256.1485 & 225.0508 & 212.4305 \\
\hline
\end{tabular}

Berdasarkan dari hasil analisis perbandingan citra multispektral sebelum ditajamkan dan sesudah ditajamkan dapat disimpulkan

\section{1) Nilai Min dan Max}

Nilai min dan max pada citra dibagi menjadi tiga layer atau tiga band yaitu red, green dan blue, jika dilihat pada satellite Landsat 8 red, green dan blue terletak pada band 4, band 3 dan band 2 . Berdasarkan nilai min dan max pada tiap band di sample A dan B, nilai band max paling tinggi terdapat pada band 4 (Red) yang berfungsi untuk pencitraan benda buatan manusia, dalam air hingga 30 kaki $(9 \mathrm{~m})$ dalam, tanah, dan vegetasi. Nilai min dan max antara citra sebelum lebih besar dibandingkan dengan citra yang sudah ditajamkan, untuk nilai max band 4 pada sampel A mempunyai rata-rata selisih yaitu 8850 (44.3\%) untuk band 3 yaitu $7947(43.1 \%)$ dan band 2 sebesar 7542 (41.8\%) sedangkan untuk sampel B nilai max band 4 yaitu 12627 (46.4\%), band 310317 (43\%) dan band 28923 (41.7\%). Untuk nilai min pada sampel B yaitu 0 , berarti nilainya berupa citra hitam/Null.

\section{2) Mean}

Berdasarkan tabel di atas, nilai Mean dari citra sebelum ditajamkan pada sampel A jauh lebih besar dari citra sesudah ditajamkan rata-rata selisih sebesar 5439.658 atau 33.3\%, begitu juga dengan sampel B rata-rata selisih antar sebelum dan sesuah di tajamkan sebesar 5583.174 atau 33.3\%, ini dikarenakan kerapatan dari citra yang sudah ditajamkan meningkat dan otomatis nilai dari $\mathrm{M}$ (baris) dan $\mathrm{N}$ (kolom) sebagai pembagi dari jumlah nilai pikel lebih besar dari citra sebelum ditajamkan. Sehingga analisis citra dari nilai mean didapat bahwa citra yang sudah ditajamkan memliki mean yang lebih sedikit karena memiliki ukuran baris dan kolom yang lebih banyak sebesar 33,3\%

3) Standar Deviasi

Standard deviation (SD) yang didapat dari kedua sampel citra yaitu citra sebelum ditajamkan mempunyai lebih besar nilai standar deviasi ketimbang dengan citra sesudah ditajamkan, yaitu rata-rata selisih 538.2098 pada sampel A dan 219.9824 pada sampel B. Standar Deviasi merupakan cerminan dari rata-rata penyimpangan data dari mean. Standar Deviasi dapat menggambarkan seberapa jauh bervariasinya data. Jika nilai SD jauh lebih besar dibandingkan nilai mean, maka nilai mean merupakan representasi yang buruk dari keseluruhan data. Sedangkan jika nilai Standar Deviasi sangat kecil dibandingkan nilai mean, maka nilai mean dapat digunakan sebagai representasi dari keseluruhan data.

\section{KESIMPULAN}

Berdasarkan hasil dari penajaman citra dan analisis hasil dari pengukuran kualitas citra yang ditajamkan, maka didapat beberapa kesimpulan sebagai berikut.

1) Dari hasil nilai Mean, citra sebelum ditajamkan memiliki besaran nilai lebih besar dibandingkan dengan citra yang sudah ditajamkan yaitu sebesar $33.3 \%$ lebih besar, begitu juga dengan nilai Standar Deviasi, jadi dapat disimpulkan setelah ditajamkan dengan metode Brovey kerapatan pixel bertambah dan membuat citra semakin jelas, tetapi nilai mean dan standar deviasi berkurang karena kelemahan dari metode Brovey itu sendiri yang tidak dapat mengambil nilai mean dan standar deviasi dari citra awal

2) Nilai min dan max dari tiap band citra sebelum ditajamkan lebih besar dibandingakan dengan citra yang sudah ditajamkan tetapi jumlah pixel dari citra pansharpening lebih banyak.

3) Metode Brovey dapat meningkatkan kualitas citra, tetapi tidak disarankan jika ingin mengambil nilai spectral dari citra awal.

4) Satelit Landsat 8 yang memiliki banyak band dengan masing-masing band berfungsi untuk melakukan fungsi tertentu, misalnya untuk deteksi vegetasi atau objek non vegetasi.

\section{REFERENSI}

[1] Jane. Elysabeth. Fusi Citra Landsat 7 ETM+ Multispektral dan Pankromatik Untuk Meningkatkan Hasil Klasifikasi. Universitas Gadjah Mada. 2013. 
Majalah Ilmiah Teknologi Elektro, Vol. 18, No. 3, September-Desember 2019

DOI: https://doi.org/10.24843/MITE.2019.v18i03.P08

[2] Oktaviani, Amelia, Yarjohan. Perbandingan Resolusi Spasial, Temporal, Dan Radiometrik Serta Kendalanya. Jurnal Enggano Vol. 1, No. 2, September 2016:74-79. 2016

[3] Sutanto. Penginderaan Jauh Jilid I. Cetakan 2. Gadjah Mada University Press. Yogyakarta. 1992

[4] Sutanto, Penginderaan Jauh Jilid I. Gadjah Mada University Press. Yogyakarta. 1986

[5] Wandayani, A. Perbandingan Metode Brovey dan PCA Dalam Fusi Citra Panchromatic dan Multispectral. Institut Pertanian Bogor. Bogor. 2007

[6] Wiweka. Standarisasi Klasifikasi Dan Simbol Lahan Perkotaan Diturunkan Dari Citra Resolusi Spasial Tinggi. Pusat Pemanfaatan Penginderaan Jauh, Lembaga Penerbangan dan Antariksa Nasional. 2013

[7] Puntodewo,A, Dewi,S, Tarigan, J. Sistem Informasi Geografis Untuk Pengelolaan Sumberdaya Alam. Center For International Forestry Researchifor, 2003:90-112. Bogor, Indonesia. 2003

[8] Kurniadi, Komang. Aplikasi Penghitungan Gross Primary Production Dari Data Penginderaan Jauh. Lontar Komputer Vol. 7, No. 1, April 2016

[9] Sitanggang, Gekomaria. Teknik Dan Metode Fusi (Pansharpening) Data Alos (Avnir-2 Dan Prism) Untuk Identifikasi Penutup Lahan/Tanaman Pertanian Sawah. Majalah Sains dan Teknologi Dirgantara Vol. 3 No. 1 Maret 2008:33-49, Pusat Pengembangan Pemanfaatan, LAPAN. Jawa Timur. 2013

[10] Santi, Rina, Eniyati.Sri. Implementasi Statistik Dengan Database Mysql.Jurnal Teknologi Informasi DINAMIK Vol. 20, No. 2 Juli 2015:132-139. 2015

I Made Dhanan Pradipta : Penajaman Citra Satelit Landsat ... 
$\{$ Halaman ini sengaja dikosongkan \} 